\title{
Coxiella and Bartonella spp. in bats (Chiroptera) captured in the Brazilian Atlantic Forest biome
}

\author{
Michelle Santos Ferreira', Alexandro Guterres ${ }^{1}$, Tatiana Rozental ${ }^{1 *}$, Roberto Leonan Morim Novaes², \\ Emmanuel Messias Vilar ${ }^{3}$, Renata Carvalho de Oliveira ${ }^{1}$, Jorlan Fernandes ${ }^{1}$, Danielle Forneas ${ }^{1}$, \\ Adonai Alvino Junior', Martha Lima Brandão ${ }^{4}$, José Luis Passos Cordeiro ${ }^{4}$, Martín Roberto Del Valle Alvarez ${ }^{5}$, \\ Sergio Luiz Althoff ${ }^{6}$, Ricardo Moratelli ${ }^{4}$, Pedro Cordeiro-Estrela ${ }^{3}$, Rui Cerqueira da Silva ${ }^{7}$ \\ and Elba Regina Sampaio de Lemos ${ }^{*}$
}

\begin{abstract}
Background: The role of bats as reservoirs of zoonotic agents, especially pathogenic bacteria such as Bartonella and Coxiella, has been discussed around the world. Recent studies have identified bats as potential hosts of species from the proteobacteria phylum. In Brazil, however, the role of bats in the natural cycle of these agents is poorly investigated and generally neglected. In order to analyze the participation of bats in the epidemiology of diseases caused by Bartonella, Coxiella, Rickettsia, Anaplasma and Ehrlichia, we conducted a descriptive epidemiological study in three biogeographic regions of the Brazilian Atlantic Forest.

Results: Tissues of 119 bats captured in preserved areas in the states of Rio de Janeiro, Bahia and Santa Catarina from 2014 to 2015 were submitted to molecular analysis using specific primers. Bartonella spp. was detected in 22 spleen samples (18.5\%, 95\% Cl: 11.9-26.6), whose phylogenetic analysis revealed the generation of at least two independent clusters, suggesting that these may be new unique genotypes of Bartonella species. In addition, four samples (3.4\%, 95\% Cl: 0.9-8.3) were positive for the htpAB gene of C. burnetii [spleen (2), liver (1) and heart (1)]. Rickettsia spp., Anaplasma and Ehrlichia were not identified. This is the first study reporting C. burnetii and Bartonella spp. infections in bats from the Atlantic Forest biome.
\end{abstract}

Conclusions: These findings shed light on potential host range for these bacteria, which are characterized as important zoonotic pathogens.

Keywords: Coxiella burnetii, Bartonella, Zoonotic bacterial agent, Mammals, Atlantic Forest hotspot, Brazil

\section{Background}

Bacteria transmitted by arthropods belonging to the genera Rickettsia, Bartonella, Coxiella, Ehrlichia and Anaplasma are pathogens of domestic and wild animals as well as humans. These agents cause diseases that may be severe and have a widespread geographic distribution, such as bartonelosis, ehrlichiosis, anaplasmosis, spotted fever, and Coxielosis/Q fever [1-4]. Bartonella spp. (proteobacteria $\alpha 2$

\footnotetext{
* Correspondence: rozental@ioc.fiocruz.br; elemos@ioc.fiocruz.br

${ }^{1}$ Laboratório de Hantaviroses e Rickettsioses, Pavilhão Helio e Peggy Pereira,

1 Pavimento, Instituto Oswaldo Cruz, Fundação Oswaldo Cruz, Avenida Brasil 4365, Manguinhos, Rio de Janeiro, RJ, Brazil

Full list of author information is available at the end of the article
}

group), an intracellular hemotropic bacterium that grows fastidiously, is transmitted mainly by flea bites [4]. Coxiella burnetii (proteobacteria $\gamma$ group), the causative agent of $\mathrm{Q}$ fever/Coxiellosis, is a highly infectious zoonotic intracellular bacterium transmitted by inhalation of aerosols or contaminated excreta materials. Ticks are suspected of having a role in the transmission of this pathogen among animals [5]. Rickettsia (proteobacteria $\alpha 1$ group) is a representative genus group of pathogenic or non-pathogenic intracellular bacteria transmitted by ticks, mites, lice and fleas [2]. Ehrlichia and Anaplasma (proteobacteria $\alpha 1$ group), which are known to cause diseases in animals and humans, are kept in the wild in a cycle involving mammals and arthropods

(c) The Author(s). 2018 Open Access This article is distributed under the terms of the Creative Commons Attribution 4.0 International License (http://creativecommons.org/licenses/by/4.0/), which permits unrestricted use, distribution, and 
[6]. In recent years, studies have pointed to bats as hosts of these proteobacteria around the world [7-11]. Their increasing diversity and apparent clade-specific association for Bartonella spp. [12] encourages increasing inventory and surveillance efforts, especially in sylvatic environments to better understand their natural transmission cycles.

Bats (order Chiroptera) occur in all continents except Antarctica [13]. Among mammals, they are outnumbered only by rodents in species richness but surpass all other groups in dietary diversity, including fruit eaters, nectar feeders, insectivores, carnivores, blood feeders and omnivores. In biodiversity hotspots such as Brazil's Atlantic Forest, bats are the most diverse and abundant mammals, and they represent wild vertebrates that interact with humans [14] especially in urban areas [15]. The role of bats as important hosts for emerging human diseases has gained the attention of the scientific community. They are recognized for harboring viral infectious agents and, less recognizably, bacterial agents of public health importance [16-18].

In Brazil, the vespertilionid bat species Histiotus velatus (tropical big-eared brown bat), and the phyllostomids Carollia perspicillata (Seba's short-tailed bat) and Desmodus rotundus (common vampire bat) were considered reservoirs of rickettsiae in an experimental study in the 1950s [19]. After more than 50 years, in the city of São Paulo, molossid, vespertilionid and phyllostomid bats were seroreactive to, at least, one rickettsial antigen of the spotted fever group [20]. In Queensland, Australia, in 2014, the DNA of C. burnetii was found in bat urine pools of a Pteropus (Pteropodidae) [8]. This finding might be indicative of the potential role of these animals as a source of infection for humans and other animal species through the inhalation of contaminated aerosols. Probably related to their sporulation process, C. burnetii survives for long periods in the environment, and inhalation is characterized as the main mechanism by which this microorganism is transmitted [21-23].

In addition, there are studies around the world in which from different species of Bartonella has been detected in bats for example, in, Peru [24], Kenya [25], United Kingdom [26], Guatemala [27], Nigeria [7], Puerto Rico [28], Vietnam [9], Costa Rica [10] and Taiwan [29]. More recently, strains of Bartonella mayotimonensis, a recognized human pathogen, were identified and isolated from bats in the northern hemisphere [30]. In Brazil, up to now, there is one study associating Bartonella with bats [11]. However, the real role of bats as hosts and maintainers of the natural cycle of these bacteria in nature remains unknown. Studies proving associations between bats and C. burnetii, Ehrlichia and Anaplasma have not yet been reported.

Considering the growing importance of bats as potential reservoirs and transmitters of different pathogens around the world as well as the paucity of investigations about the role of bats in the dissemination of proteobacteria pathogens, the present study provides information about the circulation of these zoonotic bacteria in bats captured in three Atlantic Forest localities in Brazil where notifications of Brazilian spotted fever, Q fever and bartonelosis have been reported.

\section{Methods}

\section{Study areas and sample collection}

The study was conducted in three Brazil's Atlantic Forest localities: Oswaldo Cruz Foundation (Fiocruz) Atlantic Forest Biological Station (EFMA; 22 ${ }^{\circ} 56^{\prime} 22.9^{\prime \prime S} 43^{\circ} 24^{\prime}$ $12.2 " \mathrm{~W})$, Pedra Branca Massif, Jacarepaguá, which is a metropolitan area of the city of Rio de Janeiro (RJ); city of Igrapiúna, southern region of Bahia (BA), which is within the Environmental Protection Area (APA) of Pratigi $\left(13^{\circ}\right.$ 50'43.3"S 39 16'17.0"W); Serra do Tabuleiro State Park (PEST; 27 $44^{\prime} 30.8^{\prime \prime S} 48^{\circ} 48^{\prime} 26.7^{\prime \prime} \mathrm{W}$ ), which is located in the central-eastern region of Santa Catarina state (SC) in the metropolitan area of the city Florianópolis (Fig. 1). The vegetation of the three sampling areas are composed by lowland humid forest areas from three different biogeographic regions of the Atlantic Forest biome.

From December 2013 to May 2015, expeditions were carried out and bats were captured using 10 ground-level mist nets $(9 \times 3 \mathrm{~m})$ each night in forest edges or along pre-existing trails. Permits for field collection were granted by an Brazilian Institute of Environment and Renewable Natural Resources (IBAMA) license under process numbers 19,037-1; Santa Catarina's Environment Foundation (FATMA) no. 043/2014/GERUC/DPEC, Chico Mendes Biodiversity Conservation Institute (ICMBio/SISBIO) no. 26934-1 and no. 17131-4 (ICMBio/SISBIO). Adult males and non-pregnant and non-lactating adult females were euthanized. The euthanasia method consisted of cardiac puncture exsanguination performed after the anesthesia procedure of the animal, according to previously established protocols [31]. Efforts were made to minimize animal suffering following protocols approved by the Institutional Ethics Committee on Animal Research (CEUA) of the Oswaldo Cruz Foundation under process numbers CEUA P.62/11-3 (LW-68/12) and P.42/12-1 (LW-81/12).

The sex, age class and biometry of each bat were registered. Bats tissues (i.e., kidney, liver, spleen, lung and heart) were sampled and preserved in absolute ethanol. Tissue samples were obtained in accordance with recommended safety procedures and followed previously established standard protocols [32]. Bat species was identified following the identification keys available in Gardner [33] and nomenclature in Nogueira et al. [34]. Voucher specimens were deposited at scientific collections from each region where the study was performed: Federal University of Rio de Janeiro, for bats collected in Rio de Janeiro; State University of Santa 


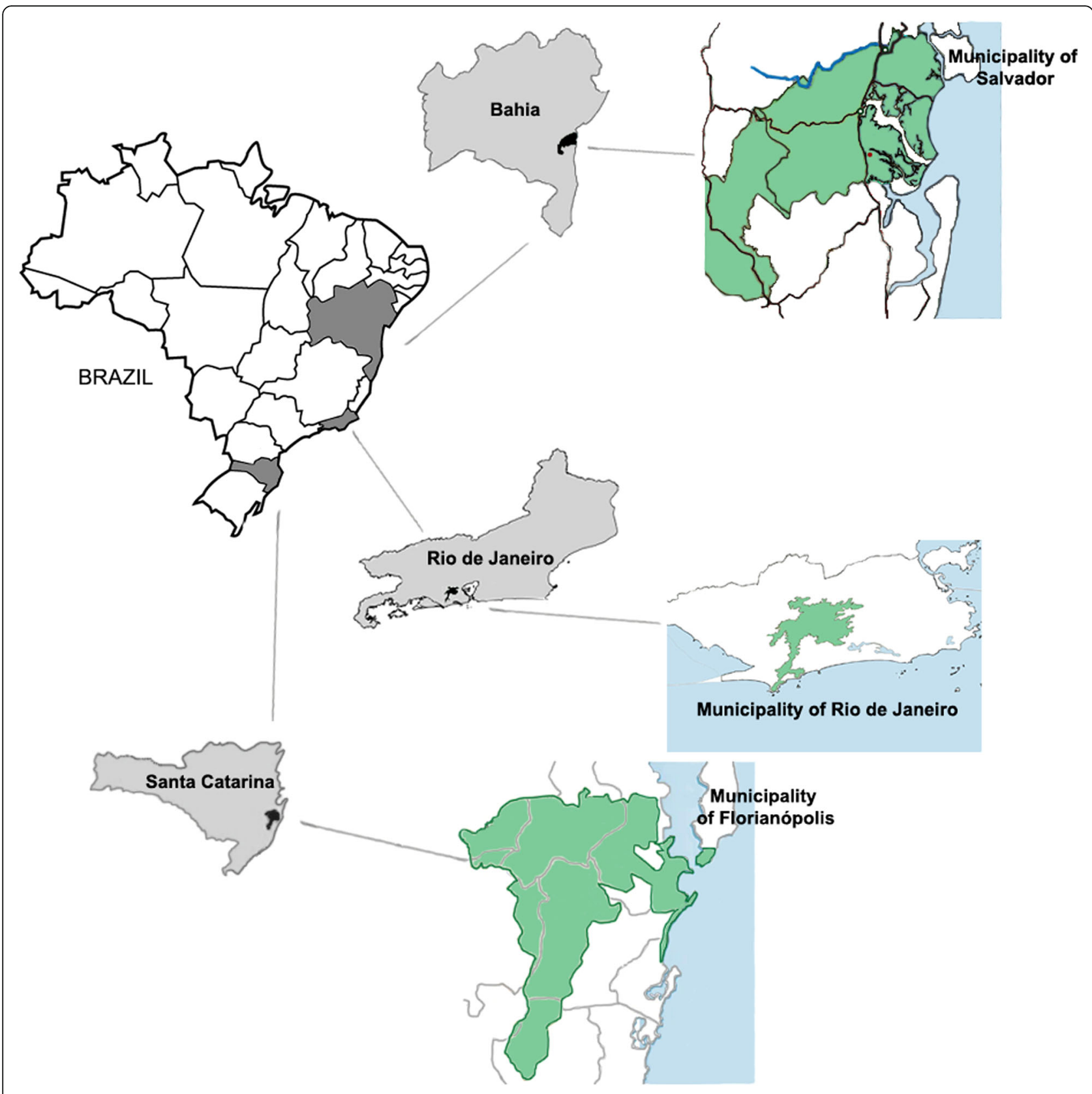

Fig. 1 Geographic location of sampling sites in the Atlantic Forest of Brazil

Cruz, for bats from Bahia; Foundation University of Blumenal and in the Collection of Mammals of the Federal University of Paraíba, for bats collected in Santa Catarina state. Prevalences and approximated confidence intervals (CIs) were calculated using the package "binom". To evaluate the influence of the sex-ratio on the positivity we use a Fisher exact's test.

\section{Nucleic acid extraction}

The DNA extraction procedures were performed in laminar flow biosafety cabinet in a Biosafety Level 3 laboratory (Vecobiosafe, Veco, Campinas, SP, Brazil). DNA was extracted from $10 \mathrm{mg}$ of each bat tissue using the commercial QIAamp DNA Mini Kit (QIAGEN, Valencia, CA, USA) according to the manufacturer's instructions. The final volume of $100-\mu \mathrm{l}$ obtained after elution in AE buffer (QIAGEN, Valencia, CA, USA). Negative controls using nuclease-free water were included in each extraction to check for DNA contamination.

Spleen tissues were investigated for all agents covered in this study; however, in an attempt to identify 
complementarity of information for Coxiella burnetii research, other tissues were tested as well.

\section{PCR amplification}

Conventional polymerase chain reaction (PCR) assays was used to detect the target genes. The gene for which each agent investigated in this study was tested is listed below and demonstrated in Table 1. Bartonella spp., gltA gene [35]. Coxiella burnetii, bacterial-specific primers designed to amplify the IS1111 gene [36, 37]. Rickettsia spp., a partial sequence of the gltA gene [35]. Ehrlichia and Anaplasma bacterial,16S rRNA gene [38].

The mixture to each reaction contained $2.5 \mu \mathrm{l}$ of $10 \mathrm{X}$ PCR buffer, $0.6 \mu \mathrm{l}$ of $10 \mathrm{mM}$ of each primer, $0.75-2 \mu \mathrm{l}$ of $50 \mathrm{mM} \mathrm{MgCl} 2,0.25 \mu \mathrm{l}$ deoxynucleotides $(20 \mathrm{mM}$ of each deoxynucleotide triphosphate), $0.1 \mu \mathrm{l}$ Taq Platinum DNA polymerase (5 U/ $\mu$ l Invitrogen, Carlsbad, CA, USA) and nuclease-free water (Promega, Madison, WI, USA) to obtain a final volume of $25 \mu \mathrm{l}$. The volumes of the DNA sample varied as a function of the primer used. To Bartonella spp. was used $3 \mu \mathrm{l}$; to Rickettsia spp., $3 \mu \mathrm{l}$ for PCR 1 and $2 \mu \mathrm{l}$ for nested PCR; to C. burnetii,4 $\mu \mathrm{l}$ for PCR 1 and $2 \mu \mathrm{l}$ for nested PCR; to Ehrlichia and Anaplasma spp., $2.5 \mu \mathrm{l}$. Volumes pre-established in a previous study [35]. Negative controls using nuclease-free water were included in each
PCR assay to check for possible DNA contamination. Genomic DNA extracted from positive clinical samples from the National Reference Laboratory for Rickettsioses were used as positive controls. PCR amplification was subjected to a $1.5 \%$ agarose gel, stained with GelRed ${ }^{\mathrm{TM}}$ (Biotium, Hayward, CA, USA).

\section{DNA sequencing and phylogenetic analyses}

Appropriately sized fragments were purified using Illustra GFX PCR DNA and Gel Band Purification ${ }^{\bullet}$ kit (GE Healthcare, Buckinghamshire, UK), direct nucleotide sequencing amplicon was performed using the BigDye Terminator v3.1 Cycle Sequencing kit, and purification was performed using the BigDye ${ }^{\oplus} \mathrm{X}$-Terminator Purification kit (Applied Biosystems, Foster City, CA, USA), according to the manufacturer's recommendations. The analyses of the amplicons were performed in an ABI Prism 3730XL with 96 capillaries (Applied Biosystems) and the nucleotide sequences were analyzed using MEGA7 software (downloaded from www.megasoftware.net). A consensus sequence for each bacterial genome was derived from contiguous sequences assembled with the same software.

Multiple sequence alignments were done with sequences obtained from this study and sequences from the GenBank using MUSCLE in the SeaView v.4 program [39]. The

Table 1 Oligonucleotide primers used for screening bat samples of Coxiella burnetii, Bartonella spp., Rickettsia spp., Ehrlichia spp. and Anaplasma spp.

\begin{tabular}{|c|c|c|c|c|c|c|}
\hline Pathogen & Target gene & Oligonucleotide primer & Primer sequence $\left(5^{\prime}-3^{\prime}\right)$ & $\begin{array}{l}\text { Amplicon } \\
\text { size (bp) }\end{array}$ & Cycling conditions & Reference \\
\hline Coxiella burnetii & IS1111 & $\begin{array}{l}\text { Outer primer } F \\
\text { Outer primer } \mathrm{R} \\
\text { Nested primer } \mathrm{F} \\
\text { Nested primer } \mathrm{R}\end{array}$ & $\begin{array}{l}\text { TATGTATCCACCGTAGCCAGC } \\
\text { CCCAACAACACCTCCTTATTC } \\
\text { AAGCGTGTGGAGGAGCGAA } \\
\text { CC } \\
\text { CTCGTAATCACCAATCGCT } \\
\text { TCGTC }\end{array}$ & $\begin{array}{l}687 \mathrm{bp} \\
440 \mathrm{bp}\end{array}$ & $\begin{array}{l}95^{\circ} \mathrm{C} \text { for } 5 \text { min, } \\
40 \text { cycles of } 95^{\circ} \mathrm{C} \\
\text { for } 30 \mathrm{~s}, 60{ }^{\circ} \mathrm{C} \text { for } \\
30 \mathrm{~s}, 72{ }^{\circ} \mathrm{C} \text { for } 1 \text { min, } \\
\text { final extension of } \\
72{ }^{\circ} \mathrm{C} \text { for } 7 \mathrm{~min} \\
95^{\circ} \mathrm{C} \text { for } 5 \mathrm{~min} \text {, } \\
30 \mathrm{cycles} \text { of } 95^{\circ} \mathrm{C} \\
\text { for } 30 \mathrm{~s}, 66^{\circ} \mathrm{C} \text { for } \\
30 \mathrm{~s}, 72{ }^{\circ} \mathrm{C} \text { for } 30 \mathrm{~s} \text {, } \\
\text { final extension of } \\
72{ }^{\circ} \mathrm{C} \text { for } 5 \text { min }\end{array}$ & $\begin{array}{l}{[36]} \\
{[35,37]}\end{array}$ \\
\hline Bartonella spp. & gltA & $\begin{array}{l}\text { Outer primer } \mathrm{F} \\
\text { Outer primer } \mathrm{R}\end{array}$ & $\begin{array}{l}\text { GCTATGTCTGCVITCT } \\
\text { ATCAYGA } \\
\text { AGAACAGTAAACATTTCN } \\
\text { GTHGG }\end{array}$ & $731 \mathrm{bp}$ & $\begin{array}{l}95^{\circ} \mathrm{C} \text { for } 10 \text { min, } 35 \\
\text { Cycles of } 95^{\circ} \mathrm{C} \text { for } 30 \mathrm{~s} \text {, } \\
58{ }^{\circ} \mathrm{C} \text { for } 30 \mathrm{~s}, 72{ }^{\circ} \mathrm{C} \text { for } \\
1 \mathrm{~min} \text {, final extension } \\
\text { of } 72{ }^{\circ} \mathrm{C} \text { for } 8 \text { min }\end{array}$ & {$[35]$} \\
\hline Rickettsia spp. & gltA & $\begin{array}{l}\text { Outer primer } F \\
\text { Outer primer } \mathrm{R} \\
\text { Nested primer } \mathrm{F} \\
\text { Nested primer } \mathrm{R}\end{array}$ & $\begin{array}{l}\text { CATCCTATGGCTATTATGC } \\
\text { TTGC } \\
\text { TATACTCTCTATG(T/A)AC(A/ } \\
\text { G)T(A/G)ACC } \\
\text { CTTACCGCTATTAGAATGA } \\
\text { TTGC } \\
\text { GAGCGA(T/G)AGCTTCAAG(T/ } \\
\text { C)TCTAT }\end{array}$ & $\begin{array}{l}885 \mathrm{bp} \\
572 \mathrm{bp}\end{array}$ & $\begin{array}{l}95^{\circ} \mathrm{C} \text { for } 10 \mathrm{~min}, 30 \\
\text { cycles of } 95{ }^{\circ} \mathrm{C} \text { for } 30 \mathrm{~s} \text {, } \\
55^{\circ} \mathrm{C} \text { for } 40 \mathrm{~s}, 72{ }^{\circ} \mathrm{C} \text { for } \\
55 \mathrm{~s} \text {, final extension of } \\
72{ }^{\circ} \mathrm{C} \text { for } 10 \mathrm{~min} \\
95^{\circ} \mathrm{C} \text { for } 7 \mathrm{~min}, 25 \text { cycles } \\
\text { of } 95^{\circ} \mathrm{C} \text { for } 30 \mathrm{~s}, 63^{\circ} \mathrm{C} \text { for } \\
30 \mathrm{~s}, 72{ }^{\circ} \mathrm{C} \text { for } 35 \mathrm{~s} \text {, final } \\
\text { extension of } 72{ }^{\circ} \mathrm{C} \text { for } 10 \mathrm{~min}\end{array}$ & $\begin{array}{l}{[35]} \\
{[35]}\end{array}$ \\
\hline $\begin{array}{l}\text { Ehrlichia spp. } \\
\text { /Anaplasma spp. }\end{array}$ & 16 s rRNA & $\begin{array}{l}\text { Outer primer } F \\
\text { Outer primer } \mathrm{R}\end{array}$ & $\begin{array}{l}\text { GGTACCYACAGAAGAAGTCC } \\
\text { TGCACTCATCGITIACAG }\end{array}$ & $345 \mathrm{bp}$ & $\begin{array}{l}95^{\circ} \mathrm{C} \text { for } 3 \mathrm{~min}, 35 \text { cycles } \\
\text { of } 95^{\circ} \mathrm{C} \text { for } 15 \mathrm{~s}, 55^{\circ} \mathrm{C} \text { for } \\
30 \mathrm{~s}, 72{ }^{\circ} \mathrm{C} \text { for } 30 \mathrm{~s} \text {, final } \\
\text { extension of } 72{ }^{\circ} \mathrm{C} \text { for } 5 \text { min }\end{array}$ & [38] \\
\hline
\end{tabular}


best-fit evolutionary model was determined using MEGA version 7 by the Bayesian Information Criterion [40]. The phylogenetic tree was estimated using two methods: (a) Maximum Likelihood using PhyML implemented in SeaView v.4 [41], where the statistical support of the clades was measured by a heuristic search with 1000 bootstrap replicates; and (b) a Bayesian Markov Chain Monte Carlo (MCMC) method implemented in MrBayes v.3.2.6 [42]. The Bayesian analysis consisted of two simultaneous independent runs of 10 million MCMC generations (burn-in of 25\%).

\section{Results}

\section{Bat sampling}

A total of 119 adult bats belonging to 21 species were sampled; $n=44$ from EFMA/RJ; $n=47$ from APA Pratigi/BA and $n=28$ from PEST/SC (Table 2). The species sampled and their abundances are as follows: Carollia perspicillata ( $n=34)$, Desmodus rotundus (15), Artibeus lituratus (14), Sturnira lilium (12), Artibeus fimbriatus (7), Rhinophylla pumilio (7) Artibeus planirostris (5), Dermanura cinerea (4), Phyllostomus discolor (4), Artibeus obscurus (2), Glossophaga soricina (2), Myotis nigricans (2), Sturnira tildae (2), Vampyressa pusilla (2), Anoura caudifer (1), Chiroderma doriae (1), Lonchophylla peracchii (1), Micronycteris minuta (1), Micronycteris sp. (1), Phyllostonus hastatus (1), and Trinycteris nicefori (1).

\section{Detection of Bartonella spp.}

Bartonella DNA was detected in 22 animals (18.5\%, 95\% CI: 11.9-26.6) (Table 3) collected from the three regions of this study (Table 2): Jacarepaguá/RJ (10/44; 23.0\%, 95\% CI: 11.4-37.8); APA Pratigi/BA (7/47; 15\%, 95\% CI: 6.2-28.3) and PEST/SC (5/28; 18\%, 95\% CI: 6.0-36.8). Although S. lilium (6/22 Bartonella-positive bats) and $D$. rotundus (6/22) were the most frequent hosts of Bartonella, six other bats species (i.e., C. perspicillata, $A$. lituratus, A. fimbriatus, A. obscurus, $R$. pumilioand $P$. discolor) were also positive (Table 3 ). Contrasting the pool of males against the pool of females per locality, in all study areas we found more positive samples for males than females, but only in APA Pratigi/BA this difference was significant (Fisher exact's test $p=0.0027$ ). Due to the small sample size per species/locality, we did not run this analysis per species.

However, in this study, we opted to work with sequences that presented fragment sizes that would allow reliable results when submitted to phylogenetic analyses. Thus, of the 22 samples that were positive for the Bartonella gltA gene, 11 were included in these analyses. The phylogenetic inference based on the gltA gene sequences revealed two different clusters for the new sequences of this study (Fig. 2). In the gltA gene tree, the first cluster is composed of two groups; one of them comprised our sequence (EM 209) found in $P$. discolor in the state of Bahia as well as the sequence Bartonella sp. clone SJ114 (KJ816690) found in Carollia sowelli and the sequence Bartonella sp. clone SJ101 (KJ816666) found in Anoura geoffroyi, both from Costa Rica (1/ 99). The second group in the same cluster is composed of the sequence of Bartonella sp. clone SJ131 (KJ816670) found in Sturnira lilium from Costa Rica as a stem lineage in the clade $(1 / 85)$.The next node (1/ 100) within the cluster contained our sequences (EM 805, RM 525) found in S. lilium from the states of Santa Catarina and Rio de Janeiro (1/ 83), in a sister relation to the clade of our sequences found in $A$. fimbriatus and A. obscurus (RM 524, RM 529) from Rio de Janeiro $\left(0.79 /{ }^{*}\right)$.

The second weakly supported cluster comprises two sister groups. One (1/99) includes our three sequences (RM 512, RM 534, RM 564) found in D. rotundus from the state of Rio de Janeiro, and the other includes the sequence Bartonella sp. clone SJ117 (KJ816691) found in C. perspicillata from Costa Rica and our two sequences (EM 185, EM 199) found in C.perspicillata from Bahia state $(0.93 / 95)$. The other group is composed of the sequence of Bartonella sp. clone SJ128 (KJ816692) found in $P$. discolor from Costa Rica as a stem lineage in the group (1/94). The next bifurcation within the cluster contained our sequence (EM 819) found in S. lilium from Santa Catarina state as well as the sequence of Bartonella sp. clone 1 (KY356753) found in an undescribed bat species from Brazil and the sequence Bartonella sp. clone SJ130 (KJ816674) found S. lilium from Costa Rica (1/ 99).

\section{Detection of Coxiella burnetii}

Coxiella burnetii DNA was detected in four specimens from two bat species (3.4\%, 95\% CI: 0.9-8.3), A. lituratus (3/4 Coxiella-positive bats) and A. fimbriatus (1/4) from two different regions: Jacarepaguá/RJ (3/44; 7\%, 95\% CI: 1.4-18.6) and PEST/SC (1/28; 4\%, 95\% CI: $0.1-$ 18.3) (Tables 2 and 3). No differences between positivity in males and females were observed. Coxiella DNA sequences showed $100 \%$ identity to the complete genome of C. burnetii [GenBank CP018005, CP020616, AE 016828, LK 937696]. In our survey, co-infection was detected in one bat sample of $A$. fimbriatus from the Jacarepaguá/RJ region (Table 2). Rickettsia spp., Ehrlichia spp. and Anaplasma spp. DNA was not detected in any of the bat samples tested.

\section{Nucleotide sequence accession numbers}

All sequences obtained including 11 for Bartonella spp. gltA (MH204887-MH204897) and 4 for Coxiella burnetii IS1111 (MH229948-MH229951) have been deposited in GenBank. 
Table 2 Number of bats collected per locality ( $n$ ), total number of bats (N), and infected bats (p), 95\% confidence intervals of prevalences (Cl) by Bartonella spp. and Coxiella burnetii

\begin{tabular}{|c|c|c|c|c|c|c|c|}
\hline \multirow[t]{2}{*}{ Family: Sub-family } & \multicolumn{4}{|l|}{ Localities } & \multicolumn{3}{|l|}{ PCR assay } \\
\hline & $\begin{array}{l}\text { Jacarepagua/ } \\
\text { RJ } n / N(\%)\end{array}$ & $\begin{array}{l}\text { APA Pratigi/BA } \\
\mathrm{n} / \mathrm{N}(\%)\end{array}$ & $\begin{array}{l}\mathrm{PEST} / \mathrm{SC} \\
\mathrm{n} / \mathrm{N}(\%)\end{array}$ & $\begin{array}{l}\text { Total bats } \\
\mathrm{N}(\%)\end{array}$ & $\begin{array}{l}\text { Bartonella positive } \\
\text { p/N }(\% ; \mathrm{Cl})\end{array}$ & $\begin{array}{l}\text { Coxiella positive } \mathrm{p} / \\
\mathrm{N}(\% ; \mathrm{Cl})\end{array}$ & $\begin{array}{l}\text { Bartonella and Coxiella } \\
\text { positive } \mathrm{p} / \mathrm{N}(\% ; \mathrm{Cl})\end{array}$ \\
\hline \multicolumn{8}{|c|}{ Phyllostomidae: Carolliinae } \\
\hline Carollia perspicillata & $4 / 34(11.8)$ & 23/34(67.7) & $7 / 34(20.6)$ & $34(28.6)$ & $5 / 34(14.7 ; 4.9-31.0)$ & NS & NA \\
\hline Rhinophylla pumilio & $0 / 7(0)$ & $7 / 7(100)$ & $0 / 7(0)$ & $7(5.9)$ & $1 / 7(14.3 ; 0.3-57.8)$ & NS & NA \\
\hline \multicolumn{8}{|c|}{ Phyllostomidae: Desmodontinae } \\
\hline $\begin{array}{l}\text { Desmodus } \\
\text { rotundus }\end{array}$ & 15/15(100) & 0/15(0) & 0/15(0) & $15(12.6)$ & 6/15(40; 16.3-67.7) & NS & NA \\
\hline \multicolumn{8}{|c|}{ Phyllostomidae: Glossophaginae } \\
\hline Anoura caudifer & $0 / 1(0)$ & $0 / 1(0)$ & 1/1 (100) & $1(0.8)$ & NS & NS & NA \\
\hline $\begin{array}{l}\text { Glossophaga } \\
\text { soricina }\end{array}$ & $2 / 2(100)$ & $0 / 2(0)$ & $0 / 2(0)$ & $2(1.7)$ & NS & NS & NA \\
\hline $\begin{array}{l}\text { Lonchophylla } \\
\text { peracchii }\end{array}$ & $1 / 1(100)$ & $0 / 1(0)$ & $0 / 1(0)$ & $1(0.8)$ & NS & NS & NA \\
\hline \multicolumn{8}{|c|}{ Phyllostomidae: Glyphonycterinae } \\
\hline Trinycteris nicefori & $0 / 1(0)$ & $1 / 1(100)$ & $0 / 1(0)$ & $1(0.8)$ & NS & NS & NA \\
\hline \multicolumn{8}{|c|}{ Phyllostomidae: Micronycterinae } \\
\hline $\begin{array}{l}\text { Micronycteris } \\
\text { minuta }\end{array}$ & $1 / 1(100)$ & $0 / 1(0)$ & $0 / 1(0)$ & $1(0.8)$ & NS & NS & NA \\
\hline Micronycteris sp. & $1 / 1(100)$ & $0 / 1(0)$ & $0 / 1(0)$ & $1(0.8)$ & NS & NS & NA \\
\hline \multicolumn{8}{|c|}{ Phyllostomidae: Phyllostominae } \\
\hline $\begin{array}{l}\text { Phyllostomus } \\
\text { discolor }\end{array}$ & $0 / 4(0)$ & $4 / 4(100)$ & $0 / 4(0)$ & $4(3.4)$ & $1 / 4(25 ; 0.6-80.5)$ & NS & NA \\
\hline $\begin{array}{l}\text { Phyllostomus } \\
\text { hastatus }\end{array}$ & $0 / 1(0)$ & $0 / 1(0)$ & $1 / 1(100)$ & $1(0.8)$ & NS & NS & NA \\
\hline \multicolumn{8}{|c|}{ Phyllostomidae: Stenodermatinae } \\
\hline Artibeus fimbriatus & $3 / 7(42.9)$ & $0 / 7(0)$ & $4 / 7(57.1)$ & $7(5.9)$ & $1 / 7(14.3 ; 0.3-57.8)$ & $1 / 7(14.3 ; 0.3-57.8)$ & $1 / 7(14.3 ; 0.3-57.8)$ \\
\hline Artibeus lituratus & 4/14(28.6) & 2/14(14.3) & $8 / 14(57.1)$ & 14(11.8) & $1 / 14(7.1 ; 0.1-33.8)$ & $3 / 14(21.4 ; 4.6-50.7)$ & NA \\
\hline Artibeus obscurus & $1 / 2(50)$ & $0 / 2(0)$ & $1 / 2(50)$ & $2(1.7)$ & $1 / 2(50 ; 1.2-98.7)$ & NS & NA \\
\hline Artibeus planirostris & $0 / 5(0)$ & $5 / 5(100)$ & $0 / 5(0)$ & $5(4.2)$ & NS & NS & NA \\
\hline Chiroderma doriae & $0 / 1(0)$ & $0 / 1(0)$ & $1 / 1(100)$ & $1(0.8)$ & NS & NS & NA \\
\hline Dermanura cinerea & $0 / 4(0)$ & 4/4(100) & $0 / 4(0)$ & $4(3.4)$ & NS & NS & NA \\
\hline Sturnira lillium & $6 / 12(50)$ & 0/12(0) & $6 / 12(50)$ & $12(10.1)$ & 6/12(50; 21.0-78.9) & NS & NA \\
\hline Sturnira tildae & $2 / 2(100)$ & $0 / 2(0)$ & $0 / 2(0)$ & $2(1.7)$ & NS & NS & NA \\
\hline Vampyressa pusilla & $2 / 2(100)$ & $0 / 2(0)$ & $0 / 2(0)$ & $2(1.7)$ & NS & NS & NA \\
\hline \multicolumn{8}{|c|}{ Vespertilionidae: Myotinae } \\
\hline Myotis nigricans & $2 / 2(100)$ & $0 / 2(0)$ & $0 / 2(0)$ & $2(1.7)$ & NS & NS & NA \\
\hline TOTAL & 44 & 47 & 28 & 119 & $22(18.5 ; 11.9-26.6)$ & $4(3.4 ; 0.9-8.3)$ & $1(0.8 ; 0.02-4.5)$ \\
\hline
\end{tabular}

NS negative sample, NA not applicable

\section{Discussion}

Considering the growing importance of bats as potential hosts of zoonotic agents of human disease, our findings reveal that bats of different species are infected with Bartonella spp. and C. burnetii in the Atlantic Forest regions of Rio de Janeiro, Bahia and Santa Catarina. In this study, we found a prevalence of $3.4 \%$ of bats positive for $C$. burnetii DNA, all belonging to the genus Artibeus. Characteristics of this genus, such as the formation of colonies grouping dozens of individuals of reproductive age [43] can contribute to a rapid and widespread transmission of C. burnetii among these animals, especially considering the high resistance of these proteobacteria, which can survive for several weeks in the environment where the 
Table 3 Specimens infected by Bartonella spp. and Coxiella burnetii. Specimens are arranged by species, locality and sex

\begin{tabular}{|c|c|c|c|}
\hline Field Number & Species & Sex & Locality \\
\hline \multicolumn{4}{|l|}{ Bartonella spp. } \\
\hline RM 510 & Desmodus rotundus & Female & Jacarepaguá - RJ \\
\hline RM 512 & Desmodus rotundus & Male & Jacarepaguá - RJ \\
\hline RM 517 & Desmodus rotundus & Female & Jacarepaguá - RJ \\
\hline RM 523 & Desmodus rotundus & Male & Jacarepaguá - RJ \\
\hline RM 524 & Artibeus fimbriatus & Male & Jacarepaguá - RJ \\
\hline RM 525 & Sturnira lilium & Female & Jacarepaguá - RJ \\
\hline RM 529 & Artibeus obscurus & Male & Jacarepaguá - RJ \\
\hline RM 532 & Sturnira lilium & Male & Jacarepaguá - RJ \\
\hline RM 534 & Desmodus rotundus & Male & Jacarepaguá - RJ \\
\hline RM 564 & Desmodus rotundus & Female & Jacarepaguá - RJ \\
\hline EM 179 & Carollia perspicillata & Male & APA do Pratigi - BA \\
\hline EM 185 & Carollia perspicillata & Male & APA do Pratigi - BA \\
\hline EM 186 & Artibeus lituratus & Male & APA do Pratigi - BA \\
\hline EM 189 & Rhinophylla pumilio & Male & APA do Pratigi - BA \\
\hline EM 199 & Carollia perspicillata & Male & APA do Pratigi - BA \\
\hline EM 209 & Phyllostomus discolor & Male & APA do Pratigi - BA \\
\hline EM 217 & Carollia perspicillata & Male & APA do Pratigi - BA \\
\hline EM 795 & Sturnira lilium & Male & PEST - SC \\
\hline EM 800 & Carollia perspicillata & Male & PEST - SC \\
\hline EM 803 & Sturnira lilium & Male & PEST - SC \\
\hline EM 805 & Sturnira lilium & Male & PEST - SC \\
\hline EM 819 & Sturnira lilium & Female & PEST - SC \\
\hline \multicolumn{4}{|c|}{ Coxiella burnetii } \\
\hline RM 514 & Artibeus lituratus & Female & Jacarepaguá/RJ \\
\hline RM 524 & Artibeus fimbriatus & Male & Jacarepaguá/RJ \\
\hline RM 557 & Artibeus lituratus & Male & Jacarepaguá/RJ \\
\hline EM 817 & Artibeus lituratus & Female & PEST /SC \\
\hline
\end{tabular}

animals were present [22]. Our results as well as recently published findings $[35,44]$ suggest the existence of a complex C. burnetii transmission cycle involving a large number of wild and domestic animals in Rio de Janeiro. In addition, the presence of $C$. burnetii DNA in bats captured in the region of Santa Catarina state is the first evidence of the circulation of this agent in the state.

Our prevalence results (18.5\%) corroborate other studies worldwide showing the prevalence of Bartonella spp. in bats between $18.0-33.3 \%$ [10, 24, 27]. In our study, S. lilium (27.3\%), D. rotundus (27.3\%) and C. perspicillata (22.7\%) were the species that presented the highest prevalence of Bartonella infection. In South America, similar results were obtained in Peru, with a prevalence of $15 \%$ for C. perspicillata (4/27), $37 \%$ for D. rotundus, (10/27) and $4 \%$ for $S$. lilium (1/27) [24]. In Brazil, in a study recently carried out in 5 different states, positive samples for Bartonella spp. were found in S. lilium, C. perspicillata, P. discolor, Glossophaga soricina and Natalus espiritosantensis (Natalusmacrourus [45]) [11]. Although we have found more positive samples for males than females in all studied areas, the evidence available, including the established knowledge on transmission routes and the role of bats in the circulation of these pathogens, do not allow us to speculate on the pathogen prevalence in males. Further analyses comparing males and females per species are necessary for better understanding the role of sexes in the pathogen circulation.

The phylogenetic tree revealed the formation of independent clades when compared to Bartonella species reported in the literature, which may indicate that previously unknown genotypes of Bartonella are infecting these bats. This is a common finding with studies of this agent in bats from other regions of the world (e.g., in Guatemala, Nigeria, Costa Rica and China) $[7,10,27,46]$. Some of our obtained sequences showed a clear separation of the group formed in Bartonella sequences found in wild rodents of the Atlantic Forest in the state of Rio de Janeiro (LBCE- Laboratory of Biology and Control of Schistosomiasis), reinforcing that a new genotype may be circulating among bats and that these strains differ between rodents and bats [35]. Interestingly, our sequences were most closely related to others identified in bats from Costa Rica and related only to a single sequence found in a Brazilian bat. Furthermore, positive samples belonging to the $S$. lilium species were grouped into two distinct clades, suggesting that a single bat species is host to two different species of Bartonella. Similarly, sequences generated from Bahia, Rio de Janeiro and Santa Catarina states subjected to phylogenetic analyses were divided into two clades and suggested that the circulation of more than one species of Bartonella may be associated with bats in each state. Co-infection of different Bartonella species in a single bat species was also observed in Kenya, Guatemala, China and Georgia [25, 27, 46, 47]. A recent study demonstrated that Bartonella strains tend to cluster according to families, super-families and suborders of bats [48]. In addition, a co-infection with different species of Bartonella in a single species of bat may imply a change of bacteria via recombination, as shown by Bartonella in rodents [49]. The presence of divergent sequences in the analyzes of this study suggests the presence of more than one Bartonella lineage, since the divergence of the sampled sequences of the gltA gene varied from 0.0 to $20.9 \%$ in sequences of the same clade, the sequence divergence among Bartonella species suggested for this fragment is about $30 \%$ [50] (Additional file 1). To characterize the Bartonella species, it is necessary to sequencing other housekeeping genes (ie, $r p o B$, fts $Z$,groEL and its) to recognize the diversity of lineages found in bats and to determine the structure of populations and phylogenetic data [51, 52]. Sequencing of the additional genes for improved taxonomic resolution was beyond the scope of this paper. 


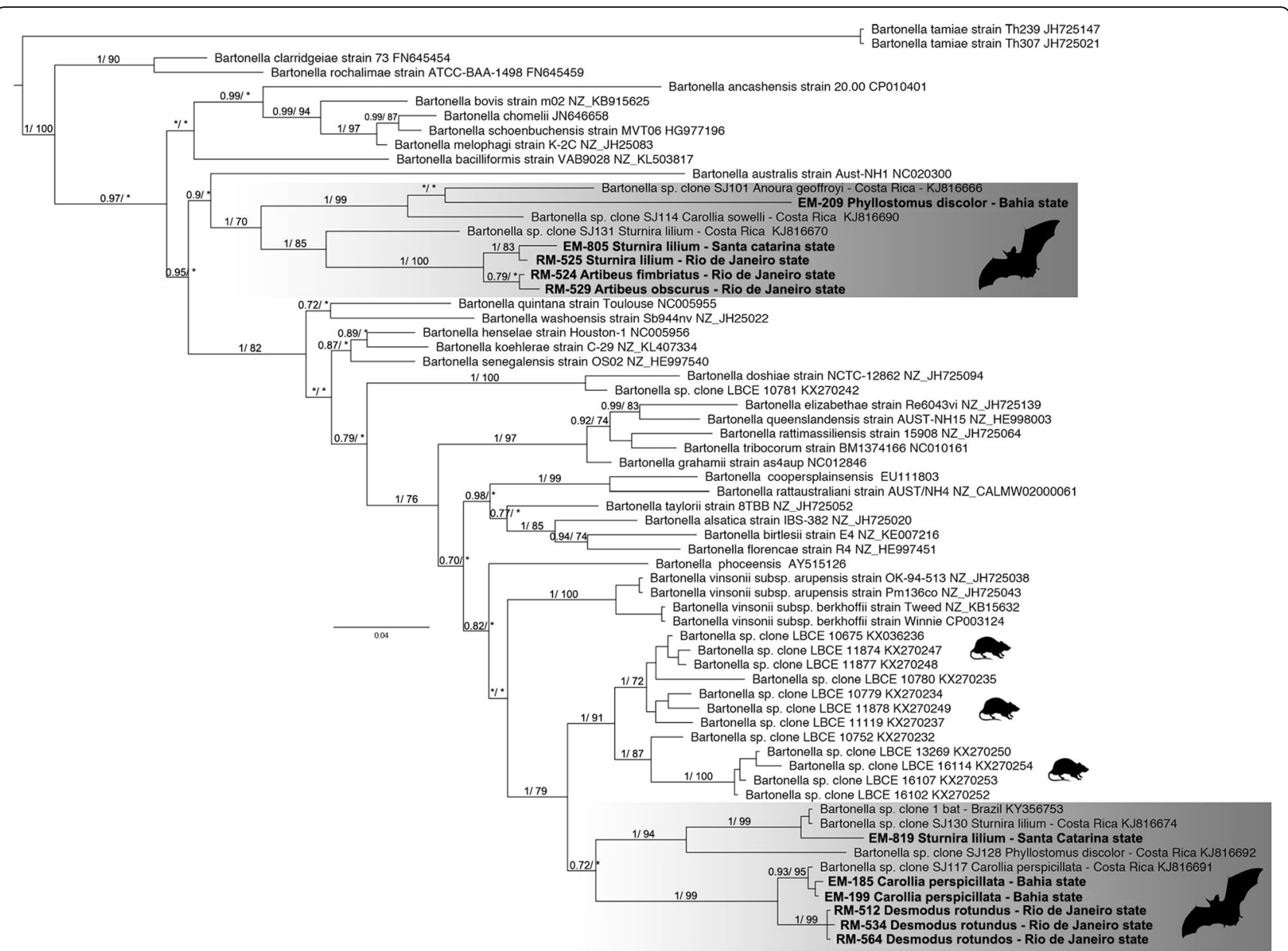

Fig. 2 Phylogenetic relationships based on the gltA gene partial (512 nt) sequences of Bartonella species. Numbers ( $\geq 0.7 / 70 \%)$ above branches indicate posterior node probabilities or bootstrap values (Bayesian/ML). *Indicate values below 0.7/70. The Tamura threeparameter model with gamma distributed rate heterogeneity $(\mathrm{T} 92+\mathrm{G})$ was selected as the best-fit evolutionary model according to the Bayesian information criterion calculated using MEGA7 [39]. The branch labels include the GenBank accession number and the species or strain

Our study has identified a co-infection with C. burnetii and Bartonella spp. in an individual of A. fimbriatus. Although a pattern cannot be established, dual infection can reinforce the potential of bats to host these bacterial pathogens. Many bat species are gregarious and can form small groups of a few individuals to large colonies of up to 20 million individuals, such as the species Tadarida brasiliensis in Bracken Cave in Texas, USA [53]. Furthermore, different bat species can cohabitate in the same shelter, allowing the possibility for interspecific transmission and a high rate of contact within these colonies that can lead to rapid transmission of pathogens [54]. Bats have been identified as potential natural reservoirs of a number of high-impact zoonotic agents. Recently, a study provided evidence that bats are indeed special in hosting more zoonotic viruses and more total viruses per species than rodents [55].
The absence of Rickettsia in bat samples corroborate the literature demonstrating that a lack of rickettsial amplification in wild animal is an expected result, since vertebrates act as amplifiers and food sources for ticks, which are in fact the true reservoirs of these proteobacteria in nature [35]. Besides, this reinforces that the role of bats as carriers of Rickettsia is still unknown, despite reports in the 1950s that bats harbor pathogenic rickettsial $[19,56,57]$. No samples tested in our study were positive for Ehrlichia and Anaplasma infections. Although bats have been found infected with proteobacteria of the families Anaplasmataceae [58], there is still no record of DNA amplification of Ehrlichia spp. or Anaplasma spp. in these mammals. Regardless of which other prior studies have used a similar method, it seems plausible that some negative detections may have resulted from a less sensitive PCR approach (i.e., conventional rather than nested). 


\section{Conclusion}

This study confirms the presence of infected bats with $C$. burnetii and Bartonella spp. in the Brazilian Atlantic Forest. To the best of our knowledge, this is the first study that reports C. burnetii infection in Brazilian bats and the first to report Bartonella spp. in the Atlantic Forest biome.

\section{Additional file}

Additional file 1: Estimates of Evolutionary Divergence between Bartonella gltA partial sequences. There were a total of 512 positions in the final dataset. Evolutionary analyses were conducted in MEGA7. Presentation of the PCR positive bats species for Bartonella spp. in this study with their respective GenBank accession numbers and the estimated divergence found between Bartonella gltA partial sequences of the gene deposited in GenBank. (DOCX 25 kb)

\section{Abbreviations}

APA: Environmental Protection Area; BA: Bahia; CEUA: Ethics Committee on Animal Research; Cls: Confidence intervals; CNPq: Conselho Nacional para o Desenvolvimento Cientifico e Tecnológico; EFMA: Fiocruz Atlantic Forest Biological Station; FAPERJ: Fundação de Amparo à Pesquisa do Estado do Rio de Janeiro; FATMA: Santa Catarina's Environment Foundation; Fiocruz: Oswaldo Cruz Foundation; IBAMA: Brazilian Institute of Environment and Renewable Natural Resources; ICMBio/SISBIO: Chico Mendes Biodiversity Conservation Institute; LBCE: Laboratory of Biology and Control of Schistosomiasis; MCMC: Bayesian Markov Chain Monte Carlo; PAPES: Strategic Health Research Program; PCR: Polymerase chain reaction; PEST: Serra do Tabuleiro State Park; PPBIO: Biodiversity Research Program; RJ: Rio de Janeiro; SC: Santa Catarina
\end{abstract}

\section{Acknowledgements}

The authors would like to thank Phyllis Romijn, Marcelo Pinto, Jairo Barreira, Maria Ogrzewalska, Endiá Almeida, Raphael Gomes and Liana Strecht for assistance with sampling process. We are in debt and very grateful to Dr. Bernardo Rodrigues Teixeira for the assistance in the statistical analysis of this work and MSc Jonathan Gonçalves for reviewing Bartonella subjects. We thank FATMA for their support for collecting licenses. We are deeply indebted to Hotel Plaza Caldas da Imperatriz for their logistic support of this work. We also thank Fernando Maciel Bruggmann for his support during planning, field work and his contagious enthusiasm.

\section{Funding}

This study was supported financially by Conselho Nacional para o

Desenvolvimento Cientifico e Tecnológico (CNPq) Project 407664/2012-2 APQ Fundação de Amparo à Pesquisa do Estado do Rio de Janeiro (FAPERJ) project E-26/010.001567/2014 APQ1, Biodiversity Research Program (PPBIO) Mata Atlântica - Rede BioMA (CNPq proc.: 457524/2012-0). RM is supported by Strategic Health Research Program (PAPES VI) Fiocruz/CNPq project 407623/2012-4.

\section{Availability of data and materials}

The sequences generated in this work are publically available from the https://www.ncbi.nlm.nih.gov/genbank/, under the numbers MH204887$\mathrm{MH} 204897$ and $\mathrm{MH} 229948-\mathrm{MH} 229951$. Other data analyzed during the current study are available from the corresponding author on reasonable request.

\section{Authors' contributions}

All authors substantially contributed to the conception and design of the study. ERSL designed and writing the study protocol. MSF, AG, RLMN, EMV, RCO, AAJ, MLB, JLPC, MRVA, SLA were responsible for bats collection, identification and analysis of the data about bats. MSF, AG, TR, JF, DF were responsible for sample tests. MSF, AG, TR, RM, PCE, ERSL participated in interpretation of results and data analysis, writing and revision of the original manuscript. PCE participated in coordinating the data collection project in the states of Santa Catarina and Bahia. RM and RCS participated in coordinating the project of data collection in the state of Rio de Janeiro. All authors read and approved the final manuscript.

\section{Ethics approval and consent to participate}

All procedures involving animals were previously approved by Institutional Ethics Committee on Animal Research, process numbers CEUA P.62/11-3 (LW-68/12) and P.42/12-1 (LW-81/12). Permits for field collection were granted by Brazilian Institute of Environment and Renewable Natural Resources license under process numbers 19,037-1; n 043/2014/GERUC/ DPEC (FATMA), $n^{\circ}$ 26,934-1 (ICMBio/SISBIO) and n 17,131-4 (ICMBio/SISBIO).

Consent for publication

Not applicable.

\section{Competing interests}

The authors declare that they have no competing interests

\section{Publisher's Note}

Springer Nature remains neutral with regard to jurisdictional claims in published maps and institutional affiliations.

\section{Author details}

'Laboratório de Hantaviroses e Rickettsioses, Pavilhão Helio e Peggy Pereira, 1 Pavimento, Instituto Oswaldo Cruz, Fundação Oswaldo Cruz, Avenida Brasil

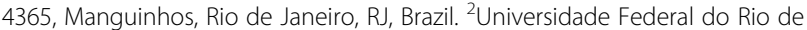
Janeiro, Av. Pedro Calmon, 550, Cidade Universitária, Rio de Janeiro, Rio de Janeiro, RJ, Brazil. 'aboratório de Mamíferos, Departamento de Sistemática e Ecologia, Centro de Ciências Exatas e da Natureza, Universidade Federal da Paraíba, Campus I, Castelo Branco, João Pessoa, PB, Brazil. ${ }^{4}$ Fundação Oswaldo Cruz, Fiocruz Mata Atlântica, Estrada Rodrigues Caldas, 3400, Taquara, Rio de Janeiro, RJ, Brazil. ${ }^{5}$ Departamento de Ciências Biológicas, Universidade Estadual de Santa Cruz, Rodovia Ilhéus - Itabuna, Km. 16 Salobrinho, Ilheus, BA, Brazil. ${ }^{6}$ Departamento de Ciências Naturais, Laboratório de Biologia Animal, Fundação Universidade Regional de Blumenau, Ccen, Dcn. FURB - Fundação Universidade Regional de Blumenau Itoupava Seca, Blumenau, SC, Brazil. 'aboratório de Vertebrados, Departamento de Ecologia, Instituto de Biologia, Universidade Federal do Rio de Janeiro, Av. Pedro Calmon, 550, Cidade Universitária, Rio de Janeiro, RJ, Brazil.

Received: 14 February 2018 Accepted: 30 August 2018

Published online: 10 September 2018

\section{References}

1. Lemos ER, Alvarenga FB, Cintra ML, Ramos MC, Paddock CD, Ferebee TL, Zaki SR, Ferreira FC, Ravagnani RC, Machado RD, Guimaraes MA, Coura JR. Spotted fever in Brazil: a seroepidemiological study and description of clinical cases in an endemic area in the state of Sao Paulo. Am J Trop Med Hyg. 2001;65(4):329-34.

2. Parola P, Paddock CD, Raoult D. Tick-borne rickettsioses around the world: emerging diseases challenging old concepts. Clin Microbiol Rev. 2005;18(4):719-56.

3. Parker NR, Barralet JH, Bell AM. Q fever. Lancet. 2006;367(9511):679-88.

4. Chomel BB, Kasten RW. Bartonellosis, an increasingly recognized zoonosis. J Appl Microbiol. 2010;109(3):743-50.

5. Porter SR, Czaplicki G, Mainil J, Guatteo R, Saegerman C. Q fever: current state of knowledge and perspectives of research of a neglected zoonosis. Int J Microbiol. 2011;2011:248418.

6. Olano JP. Human Ehrlichioses. In: Rickettsial disease, D. Raoult and P. Parola, editors. 2007. New York: Informa healthcare. p. 213-22.

7. Kamani J, Baneth G, Mitchell M, Mumcuoglu KY, Gutierrez R, Harrus S. Bartonella species in bats (Chiroptera) and bat flies (Nycteribiidae) from Nigeria, West Africa. Vector Borne Zoonotic Dis. 2014;14(9):625-32.

8. Tozer SJ, Lambert SB, Strong CL, Field HE, Sloots TP, Nissen MD. Potential animal and environmental sources of $\mathrm{Q}$ fever infection for humans in Queensland. Zoonoses Public Health. 2014;61(2):105-12.

9. Anh PH, Van Cuong N, Son NT, Tue NT, Kosoy M, Woolhouse ME, Baker S, Bryant JE, Thwaites G, Carrique-Mas JJ, Rabaa MA. Diversity of Bartonella spp. in bats, southern Vietnam. Emerg Infect Dis. 2015;21(7):1266-7.

10. Judson SD, Frank HK, Hadly EA. Bartonellae are prevalent and diverse in costa Rican bats and bat flies. Zoonoses Public Health. 2015;62:609-17.

11. Ikeda P, Seki MC, Carrasco AOT, Rudiak LV, Miranda JMD, Goncalves SMM, Hoppe EGL, Albuquerque ACA, Teixeira MMG, Passos CE, Werther K, Machado RZ, Andre MR. Evidence and molecular characterization of Bartonella spp. and hemoplasmas in neotropical bats in Brazil. Epidemiol Infect. 2017;145(10):2038-52. 
12. Mckee CD, Kosoy MY, Bai Y, Osikowicz LM, Franka R, Gilbert AT, Boonmar S, Rupprecht CE, Peruski LF. Diversity and phylogenetic relationships among Bartonella strains from Thai bats. PLoS One. 2017;12(7):e0181696.

13. Schipper J, Chanson JS, Chiozza F, Cox NA, Hoffmann M, Katariya V, Lamoreux J, Rodrigues AS, Stuart SN, Temple HJ, et al. The status of the world's land and marine mammals: diversity, threat, and knowledge. Science. 2008;322(5899):225-30.

14. Moratelli R, Calisher CH. Bats and zoonotic viruses: can we confidently link bats with emerging deadly viruses? Mem Inst Oswaldo Cruz. 2015;110(1):1-22.

15. Nunes H, Rocha FL, Cordeiro-Estrela P. Bats in urban areas of Brazil: roosts, food resources and parasites in disturbed environments. Urban Ecosyst. 2017;20(4):953-69.

16. Fenton MB, Davison M, Kunz TH, McCracken GF, Racey PA, Tuttle MD. Linking bats to emerging diseases. Science. 2006;311(5764):1098-9. author reply 1098-9

17. Calisher $\mathrm{CH}$, Childs JE, Field HE, Holmes KV, Schountz T. Bats: important reservoir hosts of emerging viruses. Clin Microbiol Rev. 2006;19(3):531-45.

18. Olival KJ, Hosseini PR, Zambrana-Torrelio C, Ross N, Bogich TL, Daszak P. Host and viral traits predict zoonotic spillover from mammals. Nature. 2017; 546(7660):646-50.

19. Magalhães O. Contribuição ao conhecimento do tifo exantemático neotrópico no Brasil. Mem Inst Oswaldo Cruz. 1953;51:463-73.

20. D'Auria SR, Camargo MC, Pacheco RC, Savani ES, Dias MA, da Rosa AR, de Almeida MF, Labruna MB. Serologic survey for rickettsiosis in bats from Sao Paulo city, Brazil. Vector Borne Zoonotic Dis. 2010;10(5):459-63.

21. Fournier PE, Marrie TJ, Raoult D. Diagnosis of Q fever. J Clin Microbiol. 1998; 36(7):1823-34.

22. Maurin M, Raoult D. Q fever. Clin Microbiol Rev. 1999;12(4):518-53.

23. Angelakis E, Raoult D. Q Fever. Vet Microbiol. 2010;140(3-4):297-309.

24. Bai Y, Recuenco S, Gilbert AT, Osikowicz LM, Gomez J, Rupprecht C, Kosoy MY. Prevalence and diversity of Bartonella spp. in bats in Peru. Am J Trop Med Hyg. 2012;87(3):518-23.

25. Kosoy M, Bai Y, Lynch T, Kuzmin IV, Niezgoda M, Franka R, Agwanda B, Breiman RF, Rupprecht CE. Bartonella spp. in bats, Kenya. Emerg Infect Dis. 2010;16(12):1875-81.

26. Concannon R, Wynn-Owen K, Simpson VR, Birtles RJ. Molecular characterization of haemoparasites infecting bats (Microchiroptera) in Cornwall. UK Parasitology. 2005;131(Pt 4):489-96.

27. Bai Y, Kosoy M, Recuenco S, Alvarez D, Moran D, Turmelle A, Ellison J, Garcia DL, Estevez A, Lindblade K, Rupprecht C. Bartonella spp. in Bats, Guatemala. Emerg Infect Dis. 2011;17(7):1269-72.

28. Olival KJ, Dittmar K, Bai Y, Rostal MK, Lei BR, Daszak P, Kosoy M. Bartonella spp. in a Puerto Rican bat community. J Wildl Dis. 2015;51(1):274-8.

29. Lin JW, Hsu YM, Chomel BB, Lin LK, Pei JC, Wu SH, Chang CC. Identification of novel Bartonella spp. in bats and evidence of Asian gray shrew as a new potential reservoir of Bartonella. Vet Microbiol. 2012;156(1-2):119-26.

30. Veikkolainen V, Vesterinen EJ, Lilley TM, Pulliainen AT. Bats as reservoir hosts of human bacterial pathogen, Bartonella mayotimonensis. Emerg Infect Dis. 2014;20(6):960-7.

31. Mills J, Childs J, Ksiazek T, Peters C. Methods for trapping and sampling small mammals for virologic testing. Department of Health and Human Services. Atlanta. 1995;

32. Lemos E, D' APS. Trabalho de campo com animais: procedimentos, riscos e biossegurança. Fiocruz: Rio de Janeiro; 2014. p. 180.

33. Gardner AL. Mammals of South America. Marsupials, xenarthrans, shrews, and bats. Vol. vol. 1. Chicago: University of Chicago Press; 2008.

34. Nogueira M, Lima I, Moratelli R, Tavares V, Gregorin R, Lúcio Peracchi A. Checklist of Brazilian bats, with comments on original records. Check List. 2014;10:808-21.

35. Rozental T, Ferreira MS, Guterres A, Mares-Guia MA, Teixeira BR, Goncalves J, Bonvicino CR, D'Andrea PS, de Lemos ER. Zoonotic pathogens in Atlantic Forest wild rodents in Brazil: Bartonella and Coxiella infections. Acta Trop. 2017;168:64-73.

36. Hoover TA, Vodkin MH, Williams JC. A Coxiella burnetti repeated DNA element resembling a bacterial insertion sequence. J Bacteriol. 1992;174(17):5540-8.

37. Mares-Guia M, Guterres A, Rozental T, Ferreira MDS, Lemos ERS. Clinical and epidemiological use of nested PCR targeting the repetitive element IS1111 associated with the transposase gene from Coxiella burnetii. Braz J Microbiol. 2017;

38. Inokuma H, Raoult D, Brouqui P. Detection of Ehrlichia platys DNA in Brown dog ticks (Rhipicephalus sanguineus) in Okinawa Island. Japan J Clin Microbiol. 2000;38(11):4219-21.
39. Edgar RC. Muscle: multiple sequence alignment with high accuracy and high throughput. Nucleic Acids Res. 2004;32(5):1792-7.

40. Kumar S, Stecher G, Tamura K. MEGA7: molecular evolutionary genetics analysis version 7.0 for bigger datasets. Mol Biol Evol. 2016;33(7):1870-4

41. Gouy M, Guindon S, Gascuel O. SeaView version 4: a multiplatform graphical user interface for sequence alignment and phylogenetic tree building. Mol Biol Evol. 2010;27(2):221-4

42. Ronquist F, Teslenko M, van der Mark P, Ayres DL, Darling A, Hohna S, Larget B, Liu L, Suchard MA, Huelsenbeck JP. MrBayes 3.2: efficient Bayesian phylogenetic inference and model choice across a large model space. Syst Biol. 2012;61(3):539-42

43. Costa LM, Prata AFD, Moraes D, Conde CFV, Jordão-Nogueira T, Esberard CEL. Deslocamento de Artibeus fimbriatus sobre o mar. Chiroptera Neotropical. 2006;12(2):289-90.

44. Mares-Guia MA, Rozental T, Guterres A, Gomes R, Almeida DN, Moreira NS, Barreira JD, Favacho AR, Santana AL, Lemos ER. Molecular identification of the agent of $\mathrm{Q}$ fever - Coxiella burnetii - in domestic animals in state of Rio de Janeiro, Brazil. Rev Soc Bras Med Trop. 2014;47(2):231-4.

45. Garbino GST, Tejedor A. Natalus macrourus (Gervais, 1856) (Chiroptera: Natalidae) is a senior synonym of Natalus espiritosantensis (Ruschi, 1951). Mammalia. 2012;77(2):237-40.

46. Han HJ, Wen H, Zhao L, Liu J, Luo LM, Zhou CM, Qin XR, Zhu YL, Zheng XX, Yu XJ. Novel Bartonella species in insectivorous bats, northern China. PLoS One. 2017;12(1)

47. Urushadze L, Bai Y, Osikowicz L, McKee C, Sidamonidze K, Putkaradze D, Imnadze P, Kandaurov A, Kuzmin I, Kosoy M. Prevalence, diversity, and host associations of Bartonella strains in bats from Georgia (Caucasus). PLoS Negl Trop Dis. 2017;11(4)

48. McKee CD, Hayman DT, Kosoy MY, Webb CT. Phylogenetic and geographic patterns of bartonella host shifts among bat species. Infect Genet Evol. 2016:44:382-94

49. Paziewska A, Harris PD, Zwolinska L, Bajer A, Sinski E. Recombination within and between species of the alpha proteobacterium Bartonella infecting rodents. Microb Ecol. 2011;61(1):134-45.

50. Norman AF, Regnery R, Jameson P, Greene C, Krause DC. Differentiation of Bartonella-like isolates at the species level by PCR-restriction fragment length polymorphism in the citrate synthase gene. J Clin Microbiol. 1995; 33(7):1797-803.

51. Maiden MC, Bygraves JA, Feil E, Morelli G, Russell JE, Urwin R, Zhang Q, Zhou J, Zurth K, Caugant DA, Feavers IM, Achtman M, Spratt BG. Multilocus sequence typing: a portable approach to the identification of clones within populations of pathogenic microorganisms. Proc Natl Acad Sci U S A. 1998; 95(6):3140-5.

52. La Scola B, Zeaiter Z, Khamis A, Raoult D. Gene-sequence-based criteria for species definition in bacteriology: the Bartonella paradigm. Trends Microbiol. 2003:11(7):318-21.

53. Peracchi AL, Lima IP, Reis NR, Nogueira MR, Ortêncio FH, Chiroptera O. In: Reis NR, Peracchi AL, Pedro WA, Lima IP, editors. Mamíferos do Brasil. Londrina: Paraná p; 2006. p. 153-230.

54. Hayman DT, Bowen RA, Cryan PM, McCracken GF, O'Shea TJ, Peel AJ, Gilbert A, Webb CT, Wood JL. Ecology of zoonotic infectious diseases in bats: current knowledge and future directions. Zoonoses Public Health. 2013; 60(1):2-21.

55. Luis AD, Hayman DT, O'Shea TJ, Cryan PM, Gilbert AT, Pulliam JR, Mills JN, Timonin ME, Willis CK, Cunningham AA, Fooks AR, Rupprecht CE, Wood JL, Webb CT. A comparison of bats and rodents as reservoirs of zoonotic viruses: are bats special? Proc Biol Sci. 2013;280(1756):1-9.

56. Magalhães O. Rickettsiasis no Brasil. Bol Oficina Sanit Panam. 1944;23:17-9

57. Magalhães O, Rocha A. Sensibilidade dos morcegos aos vírus do Tifo Exantemático Neotrópico. no Brasil Brasil-Médico. 1943;57:207-10.

58. Cicuttin GL, Boeri EJ, Beltran FJ, Gury Dohmen FE. Molecular detection of Neorickettsia risticii in Brazilian free-tailed bats (Tadarida brasiliensis) from Buenos Aires, Argentina. Pesquisa Veterinária Brasileira. 2013;33:648-50. 